\title{
Bidirectional Selection for Seed Yield in Four Populations of meskawi Barseem Clover "Trifolium alexandrinum, L."
}

\author{
M. Abd El-Sattar Ahmed ${ }^{1 *}$; Rady, Asmaa M.Samir Rady ${ }^{2}$ and Haeba, M.F. ${ }^{3}$ \\ ${ }^{1}$ Prof. of Crop Sciences, Fac. Agric., Alex. Univ. \\ ${ }^{2}$ Assoc.Prof. Crop Sciences, Fac. Agric., Alex. Univ. \\ ${ }^{3}$ Graduate students, Crop Sciences, Fac. Agric., Alex. Univ. \\ * Corresponding author
}

\begin{abstract}
Barseem clover is a rapidly growing winter annual that enjoys the largest forage productivity among forages in Egypt. Seed yield is a second product of barseem cultivations. The main objective of the recent study was to evaluate the efficiency of bidirectional selection for seed yield in four population of Meskawi barseem clover along with correlated response in forage yield. As for khadarawi population, the first cycle of selection for high seed yield $\left(\mathrm{C}_{1}{ }^{+}\right)$ gave a significant increase in seed yield reached $483.2\left(\mathrm{~g} .0 .2 \mathrm{~m}^{-2}\right)$ over base- population, and $402.5\left(\mathrm{~g} .0 .2 \mathrm{~m}^{-2}\right)$ over the average of the checks. These values amount to $42.04 \%$ over the base population or $32.73 \%$ over the average of the check varieties. The first cycle of selection for low seed yield gave insignificant increase in seed yield reached 16.4 $\left(\mathrm{g} .0 .2 \mathrm{~m}^{-2}\right)$ over the base population and $97.7\left(\mathrm{~g} .0 .2 \mathrm{~m}^{-2}\right)$ over the average of the check varieties. These increments, although, insignificant, amounted to 13.95 and $6.480 \%$ relative to the base population and the average of the checks, respectively. It was valuable to notice that, the difference between the first cycle of selection for high seed yield $\left(\mathrm{C}_{1}{ }^{+}\right)$ and the first cycle of selection for low seed yield $\left(\mathrm{C}_{1}^{-}\right)$amounted to $322.8\left(\mathrm{~g} .0 .2 \mathrm{~m}^{-2}\right)$, which represent superiority of the former by $24.65 \%$ over the latter. Regarding Meskawi population, the first cycle of selection for high seed yield significantly surpassed the base population by 559.1 (g.0.2m-2), which amount to $57.85 \%$ of the obtained seed yield from base population (C0). While, the superiority of the first cycle of selection for high seed yield over the average of the check varieties, although, amounted to 253.3 (g.0.2m-2) which is about $19.91 \%$, was not significant. Also, selection for low seed gave insignificant increase of $202.2\left(\mathrm{~g} .0 .2 \mathrm{~m}^{-2}\right)$ over the base population, which amount to $20.92 \%$. Meanwhile, the obtained seed yield from the first cycle of selection for low seed yield $\left(\mathrm{C}_{1}{ }^{-}\right)$, was inferior to the average of the checks by $-103.6\left(\mathrm{~g} .0 .2 \mathrm{~m}^{-2}\right)$ which amount to $8.14 \%$. It was valuable to notice that, the difference between the cycles of bi- directional selection $\left(\mathrm{C}_{1}{ }^{+}-\mathrm{C}_{1}{ }^{-}\right)$amounted to a significant value of $356.9\left(\mathrm{~g} .0 .2 \mathrm{~m}^{-2}\right)$ which reached $30.54 \%$ over selection for low seed yield. Concerning Helaly population, the first cycle of selection for high seed yield $(\mathrm{C} 1+)$, significantly surpassed the base population by $411.3(\mathrm{~g} .0 .2 \mathrm{~m}-2)$ which amount to $34.6 \%$ over the base population. Also, that cycle significantly surpassed the average of check varieties by 287.9 (g.0.2m-2) which amount to $21.95 \%$ over the average of the checks. He superiority of the first cycle selection for low seed yield $\left(\mathrm{C}_{1}{ }^{-}\right)$ over the base population or the average of the checks, although, reached 5.89 and $-4.07 \%$, had not reached the level of significance. The difference between bi- directional cycles of selection reached $341.3\left(\mathrm{~g} .0 .2 \mathrm{~m}^{-2}\right)$, which, represent superiority of $\left(\mathrm{C}_{1}^{+}\right)$over $\left(\mathrm{C}_{1}^{-}\right)$by $27.13 \%$.Commonly, the correlated response in green forage yield to divergent selection for seed yield was variable among the tested base population. Khadrawi population showed a negative correlated response relative to the base population when selection was practiced for high seed yield. While, in Meskawi population, selection with low seed yield was correlated with an increase in green forage yield. On the other side, in both of Serow and Helally population, a correlated negative response in green forage yield was resulted when selection was practiced for high or low seed yield. The latter responses were not measured as significant.
\end{abstract}

Key words; bidirectional selection, seed yield, barseem clover, correlated response.

\section{INTRODUCTION}

Barseem clover is a fast growing winter annual that enjoys the largest forage productivity among forages in Egypt. It is the fertility foundation of agriculture in Nile Delta and has nourished soils in the Mediterranean region for millennia. Barseem suppress weeds well during establishment and regrowth. Because of its quick germination (seven days), quick growth and winter adaptation tendency, barseem is used as a nurse crop for alfalfa. Forage quality remains acceptable until the onset of seed production.

Seed yield is a second product of barseem cultivations. The monetary value of produced seed yield per unit area is approaching similar value to seasonal forage yield. In the meantime, the yield of seed is an exportable commodity to Mediterranean basin countries that share with Egypt, barseem's cultivation.

Breeding for improved seed yield of barseem clover gained special interest in the last years. The success of programs depends upon the existing variability and the nature of genetic control on seed yield and yield component characters. Little available review regarding variability in seed yield and seed yield components of barseem clover illustrates the need for further studies. Variability in multi-cut type of barseem clover has been studied for forage yield and plant characters (Radwan and Abou-El-Fittoh 1970; Ali, 1971; El-Nahrawy, 1980; Bakheit, 1985; Mahdy,1988; Rady, 2008; Badwy, 2013; Abd ElNabyet al, 2014 and Ahmed et al, 2015). Large genetic variability has been found for seed yield and seed yield components. Recorded estimates for seed 
yield heritability reached 0.63 (Bakheit, 1989), 0.97(Ahmed, 1992), 0.52 (Martiniello and Lannucci, 1998) and 0.595 (Rajab, 2010). Farid et al., (1972) found that seed setting percentage was responsible for most of seed yield variations rather than 1000 seed weight .Phenotypic variation in seed yield amounted to $27 \%$ of obtained mean yield (Ahmed,1992), $19.0 \%$ (Martiniello and Lannucci, 1998), 27.3\% (Ahmed, 2000) and $12.7 \%$ (Rady, 2008).

Abou El-Shawareb (1971), carried out a mass and recurrent selection breeding programs in Miskawy barseem population. He reached that, five selected families through recurrent selection, had out-yielded the original population by 19.9 to $29.0 \%$ in seed yield. He concluded that, both mass and modified mass selection methods might be efficient in improving seed yield of barseem clover. Bakheit (1989), applied two generations of modified mass and family selection to Egyptian clover c.v. Fahl. Cycle one and two of half-sib family and modified mass selection along with the base population were evaluated for seed yield. The realized gains from modified mass selection were 13.23 and $16.19 \%$ over the base population for cycle one and two, respectively. The realized gain in seed yield from family selection as a percentage of the base population mean amounted to $17.47 \%$. Ahmed (2000), compared single trait with multiple trait (index selection) selection in barseem clover. Selection intensity was $10 \%$. Selection for multiple traits was significantly much rewarding than single trait selection. A realized gain in seed yield of $8.55 \%$ from index selection was obtained vs. $4.47 \%$ from single trait selection. Zbigniew (2004), studied characters that determine seed yield in hybrids of the long raceme alfalfa. He found that, seed yield per plant was positively correlated with the number of pods per raceme and the number of seed per pod. The raceme length might be an important trait in selection for seed production. Ahmed (2006 b), estimated response to three methods of recurrent selection (halfsib family selection, $S_{1}$-family selection and $S_{2}$-family selection) in 37 seed lots khadarawymulti-cut barseem population. The lowest significant gain per cycle resulted with h.s selection. Seed yield significantly increased with all selection methods. The gain from $\mathrm{S}_{1}$ selection was about double the obtained value from H.S selection and about 1.24 the obtained gain from $\mathrm{S}_{2}$ selection. Bakheitet al. (2007), applied modified mass and family selection for highly seed yield in Egyptian clover c.v.fahl. Realized gains in seed yield from cycle one and cycle two mass selections, were 13.59 and $18.45 \%$, respectively.

Table 1: Sowing dates, Cutting table and Flowering dates of barseem populations.

\begin{tabular}{|c|c|c|c|c|c|c|c|c|}
\hline \multirow{2}{*}{ Population } & \multirow{2}{*}{ Sowing date } & \multicolumn{6}{|c|}{ Cuttings } & \multirow{2}{*}{$\begin{array}{c}\text { Flowering } \\
\text { date }\end{array}$} \\
\hline & & $1^{\text {st }}$ & $2^{\text {nd }}$ & $3^{\text {rd }}$ & $4^{\text {th }}$ & $5^{\text {th }}$ & $6^{\text {th }}$ & \\
\hline Khadarawi & $15^{\text {th }}$ Oct. & $15 / 12$ & $25 / 1$ & $25 / 2$ & $25 / 3$ & $25 / 4$ & $25 / 5$ & $15 / 6$ \\
\hline Meskawi & $1^{\text {st }}$ Oct. & $1 / 12$ & $11 / 1$ & $11 / 2$ & $11 / 3$ & & & $1 / 4$ \\
\hline Serow & $15^{\text {th }}$ Nov. & $15 / 1$ & $25 / 2$ & $25 / 3$ & & & & $20 / 4$ \\
\hline Helaly & $1^{\text {st }}$ Nov. & $10 / 1$ & $20 / 2$ & $20 / 3$ & $20 / 4$ & & & $20 / 5$ \\
\hline
\end{tabular}

The main objective of the recent study was toevaluate the efficiency of bidirectional selection for clover along with correlated response in forage yield.

\section{MATERIALS AND METHODS}

The recent study was carried out at the experimental farm of Alexandria University located in Abbis 10km south of Alexandria city. Multi-cut gene pool of barseem was represented by four distinguished populations. These were Khadarwi, Meskawi, Serow and Helaly. All four populations were registered and released by the Forage Crops Research Department (FCRD), Field Crop Research Institute (FCRI), Agricultural Research Center (A.R.C), Egypt

In (2014-2015) winter season, seeds of the four populations were sown at the rate of $31.4 \mathrm{~kg}$. ha ${ }^{-1}$ in hand drilled rows $4.0 \mathrm{~m}$ long and $20 \mathrm{~cm}$ apart $(2.5 \mathrm{~g}$ per plot). Populations were timely isolated by allowing a successive flowering started with Meskawi population, then Serow, then Helaly and finally Khadarawi populations. Serow Population flowered after three cutting since sown in mid-November. Whereas, Meskawi that sown in early October flowered after four cuttings. Helaly population that was sown in early November produced four cuttings and flowered before the last (Table 1).

At flowering, 300 plants with overall visual characters in each population were selected. Those plants were left for open pollination and some heads were set in paper bags for self seed-setting .Seeds from each plant were harvested separately to represent a half-sib family. One hundred half-sib families from each population with adequate seed were saved.

In (2015-2016) winter season, half-sib families of each population were evaluated in a separate experiment. Families of each population were divided to five sets each of twenty families. Each set was evaluated in a randomized complete block experiment with three replicates. Each plot represented by a single row 1.5 long and 0.2 on apart. Seeding rate was $31.4 \mathrm{~kg}$. ha ${ }^{-1}\left(1.03 \mathrm{~g}\right.$. plot $\left.^{-1}\right)$. Families' rows were successively alternating. Sowing dates, cutting table and probable flowering dates were similar to what mentioned during the first year of the study (Table 1). Ten random plants from each plot were used to measure number of head.plant ${ }^{-1}$, seed weight and total seed weight.plant ${ }^{-1}$. seed yield in four population of meskawi barseem number of seeds.head- ${ }^{1}$, seed weight. head ${ }^{-1}, 1000$ 
Data were statistically analyzed for each population as outlined by Steel and Torrie (1980). According to the results of evaluation the highest as well as the least seed yield producing four families in each set, were identified. This resulted in selection intensity of $20 \%$.

In the same 2015/2016 season, $S_{1}$ seeds of the 100 evaluated half- sib families were planted in isolated strip, where, each family had sown in separate row of five hills spaced $20 \mathrm{~cm} . \mathrm{S}_{1}$ seeds were mixed with Fahl barseem seed to support weeds elimination during early cutting. Four cuttings were taken before flowering. Depending on family's evaluation, the excluded families were uprooted before flowering. Selected families had allowed for intercrossing to produce seeds of the first cycle of half- sib family selection for high and low seed yield.

\section{Evaluation of selection:}

In 2016 / 2017 season, the selected populations $\left(\mathrm{C}_{1}\right.$ 'S $\left.\mathrm{S}\right)$, the base populations $\left(\mathrm{C}_{0}\right.$ 'S $\left.\mathrm{S}\right)$ and two checks namely; Gemizal and Gimiza6 had evaluated. A randomized complete block design with six replications was used. Three rows/ plot of four meter length and $20 \mathrm{~cm}$ apart were used $\left(2.4 \mathrm{~m}^{2}\right.$. Seeding rates were 31.4 $\mathrm{Kg} \mathrm{ha}{ }^{-1}$. (Data had recorded from the middle three meters of the middle row in each plot). Green forage yield, had determined for four cuttings from one meter length of the middle row $\left(0.2 \mathrm{~m}^{2}\right)$. Dry matter samples were randomly taken at the time of harvest, weighed immediately, then dried at $70{ }^{\circ} \mathrm{C}$ until weight constancy. These figures were used for determining dry forage yield. Seed yield was determined from the same one meter in each plot used for forage evaluation. Statistical analysis was carried out according to Steel and Torrie (1980). M-stat-c package (1986) was used for analysis.

\section{RESULTS AND DISCUSSION}

\section{Response to divergent selection for seed yield in} barseem clover "Trifolium alexandrinum, L.":

The recent study was carried-out to evaluate the efficiency of bidirectional selection for seed yield .Multi-cut gene pool of barseem was represented by four distinguished populations. These were; Khadarwi, Meskawi, Serow and Helaly. All four populations were registered and released by the Forage Crops Research Department (FCRD), Field Crop Research Institute (FCRI), Agricultural Research Center (A.R.C), Egypt. Populations were timely isolated by allowing a successive flowering started with Meskawi population, then Serow, then Helaly and finally Khadarawi populations. Serow population flowered after three cutting since sown in mid-November. Whereas, Meskawi, that sown in early October flowered after four cuttings. Helaly population that was sown in early November produced four cuttings and flowered before the last At flowering, 300 plants with overall visual characters in each population were selected. Those plants were left for open pollination and some heads were set in paper bags for self seed-setting .Seeds from each plant were harvested separately to represent a halfsib family. One hundred half-sib families from each population with adequate seed were saved. Half-sib families of each population were evaluated in a separate experiment. According to the results of evaluation the highest as well as the least seed yield producing families were identified (selection intensity of 20\%).In the same season, $S_{1}$ seeds of the 80 evaluated half- sib families were planted in isolated strip. Selected families had allowed for intercrossing to produce seeds of the first cycle of half- sib family selection for high and low seed yield. In 2016 / 2017 season, the selected populations $\left(\mathrm{C}_{1}{ }^{\prime} \mathrm{S}\right)$, the base populations $\left(\mathrm{C}_{0}{ }^{\prime} \mathrm{S}\right)$ and two checks namely; Gemiza 1 and Gimiza 6 had evaluated. The obtained results will be presented for seed yield and correlated responses in forage yield.

\section{Response to selection for seed yield:}

Mean square of seed yield for barseem populations as affected by evaluated population were presented in Table (4). Significant $(\mathrm{P} \geq 0.05)$ differences were noticed among evaluated population in Khadarawi and Helaly populations. Meanwhile, the differences among evaluated population had not reached the level of significance in both of Meskawi and Serow populations. The difference between the base population and the first cycle of selection for high seed yield was significant $(\mathrm{P} \geq 0.01)$ in Khadrawi and Helaly populations, while, there were insignificant difference between then in Meskawi and Serow populations. On the other hand, there were insignificant difference between the base population and the evaluated population for low seed yield in all studied multi-cut barseem populations. It was valuable to notice that, the difference between the check varieties (Gemizal andGemiza 6 ) and the evaluated population for high seed yield was significant $(\mathrm{P} \geq 0.01)$ in all studied populations, but, Meskawi. Also, the difference between the evaluated population for low seed yield and the studied check varieties had not reached the level of significance in any of the studied populations. Finally, the difference between the evaluated population for high seed yield $\left(\mathrm{C}_{1}^{+}\right)$and the evaluated population for low seed yield $\left(\mathrm{C}_{1}{ }^{-}\right)$was significant $(\mathrm{P} \geq$ 0.05 ) in all populations, but, Serow.

Table (2 ): Mean squares of seed yield for barseem populations as affected by selection cycles

\begin{tabular}{|c|c|c|c|c|c|}
\hline \multirow{2}{*}{ Source of variation } & \multirow{2}{*}{ d.f. } & \multicolumn{4}{|c|}{ M.S. } \\
\hline & & Khadarawi & Meskawi & Serow & Helaly \\
\hline Replications & 5 & $116575.9^{\text {n.s. }}$ & $276818.1^{* * *}$ & $97220.0^{\text {n.s. }}$ & $408355.2^{* * *}$ \\
\hline Selection cycles & 4 & $229485.8^{*}$ & $51047.6^{\text {n.s. }}$ & $143466.8^{\text {n.s. }}$ & $153446.1^{*}$ \\
\hline $\mathrm{C}_{0} v \mathrm{~s} . \mathrm{C}_{1}^{+}$ & 1 & $700475.7^{* * *}$ & $372588.7^{*}$ & $94970.2^{\text {n.s. }}$ & $507408.5^{* * *}$ \\
\hline $\mathrm{C}_{0}$ vs. $\mathrm{C}_{1}^{-}$ & 1 & $77205.3^{\text {n.s. }}$ & $122626.2^{\text {n.s. }}$ & $27793.1^{\text {n.s. }}$ & $14700.0^{\text {n.s. }}$ \\
\hline $\mathrm{C}_{1}^{+}$vs. Checks & 1 & $648067.9^{* * *}$ & $256586.2^{\text {n.s. }}$ & $530501.1^{\text {*** }}$ & $331284.7^{*}$ \\
\hline $\mathrm{C}_{1}$ vs. Checks & 1 & $25424.3^{\text {n.s. }}$ & $42929.1^{\text {n.s. }}$ & $32401.8^{\text {n.s. }}$ & $11438.3^{\text {n.s. }}$ \\
\hline $\mathrm{C}_{1}^{+}$vs. $\mathrm{C}_{1}^{-}$ & 1 & $312576.9^{*}$ & $382065.1^{*}$ & $225515.8^{\text {n.s. }}$ & $349378.6^{*}$ \\
\hline Error & 20 & 60055.8 & 65789.9 & 60794.8 & 43919.5 \\
\hline
\end{tabular}

n.s.; not significantly different

$*$ and $* *$; significance at 0.05 and 0.01 levels respectively. 


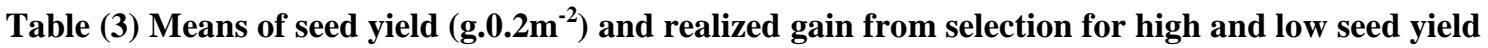
of barseem populations

\begin{tabular}{|c|c|c|c|}
\hline \multicolumn{4}{|c|}{ Serow } \\
\hline \multirow{2}{*}{ Population } & \multirow{2}{*}{ Mean } & \multicolumn{2}{|c|}{ Realized gain \% } \\
\hline & & $\mathbf{C}_{0}$ & Checks \\
\hline Base population $\left(\mathrm{C}_{0}\right)$ & 1379.6 & & \\
\hline \multicolumn{4}{|l|}{ Selected cycles } \\
\hline For high seed yield $\left(\mathrm{C}_{1}^{+}\right)$ & 1557.5 & 12.89 & 30.50 \\
\hline For low seed yield $\left(\mathrm{C}_{1}^{-}\right)$ & 1283.4 & -6.973 & 7.54 \\
\hline \multicolumn{4}{|l|}{ Checks } \\
\hline Gemiza1 & 1159.8 & & \\
\hline Giza 6 & 1226.9 & & \\
\hline Average & 1193.4 & & \\
\hline L.S.D 0.05 & N.S. & & \\
\hline \multicolumn{4}{|c|}{ Hellaly } \\
\hline \multirow{2}{*}{ Population } & \multirow{2}{*}{ Mean } & \multicolumn{2}{|c|}{ Realized gain \% } \\
\hline & & $\mathrm{C}_{0}$ & Checks \\
\hline Base population $\left(\mathrm{C}_{0}\right)$ & 1188.1 & & \\
\hline \multicolumn{4}{|l|}{ Selected cycles } \\
\hline For high seed yield $\left(\mathrm{C}_{1}^{+}\right)$ & 1599.4 & 34.61 & 21.95 \\
\hline For low seed yield $\left(\mathrm{C}_{1}^{-}\right)$ & 1258.1 & 5.89 & -4.072 \\
\hline \multicolumn{4}{|l|}{ Checks } \\
\hline Gemiza1 & 1267.8 & & \\
\hline Giza 6 & 1355.3 & & \\
\hline Average & 1311.5 & & \\
\hline L.S.D 0.05 & 252.4 & & \\
\hline \multicolumn{4}{|c|}{ Khadarawi } \\
\hline \multirow{2}{*}{ Population } & \multirow{2}{*}{ Mean } & \multicolumn{2}{|c|}{ Realized gain \% } \\
\hline & & $\mathrm{C}_{0}$ & Checks \\
\hline Base population $\left(\mathrm{C}_{0}\right)$ & 1149.2 & & \\
\hline \multicolumn{4}{|l|}{ Selected cycles } \\
\hline For high seed yield $\left(\mathrm{C}_{1}^{+}\right)$ & 1632.4 & 42.04 & 32.73 \\
\hline For low seed yield $\left(\mathrm{C}_{1}^{-}\right)$ & 1309.6 & 13.95 & 6.480 \\
\hline \multicolumn{4}{|l|}{ Checks } \\
\hline Gemiza1 & 1157.9 & & \\
\hline Giza 6 & 1301.8 & & \\
\hline Average & 1229.9 & & \\
\hline L.S.D $D_{0.05}$ & 295.1 & & \\
\hline \multicolumn{4}{|c|}{ Meskawi } \\
\hline \multirow{2}{*}{ Population } & \multirow{2}{*}{ Mean } & \multicolumn{2}{|c|}{ Realized gain \% } \\
\hline & & $\mathbf{C}_{0}$ & Checks \\
\hline Base population $\left(\mathrm{C}_{0}\right)$ & 966.4 & & \\
\hline \multicolumn{4}{|l|}{ Selected cycles } \\
\hline For high seed yield $\left(\mathrm{C}_{1}^{+}\right)$ & 1525.5 & 57.85 & 19.91 \\
\hline For low seed yield $\left(\mathrm{C}_{1}^{-}\right)$ & 1168.6 & 20.92 & -8.14 \\
\hline Checks & & & \\
\hline Gemiza1 & 1169.6 & & \\
\hline Giza 6 & 1374.8 & & \\
\hline Average & 1272.2 & & \\
\hline L.S.D $D_{0.05}$ & 338.4 & & \\
\hline
\end{tabular}


Table (4): Mean squares of green forage yield for barseem population as affected by selection cycles f or the four studied barseem population

\begin{tabular}{|c|c|c|c|c|c|}
\hline \multirow{2}{*}{ Source of variation } & \multirow{2}{*}{ d.f. } & \multicolumn{4}{|l|}{ M.S. } \\
\hline & & Khadarawi & Meskawi & Helaly & Serow \\
\hline Replications & 5 & $384.1^{*}$ & $113.7^{\text {n.s. }}$ & $204.7^{\text {n.s. }}$ & $104.7^{\text {n.s }}$ \\
\hline Selection cycles & 4 & $284.8^{\text {n.s. }}$ & $689.7^{*}$ & $62.36^{\text {n.s. }}$ & $70.09^{\text {n.s }}$ \\
\hline $\mathrm{C}_{0}$ vs. $\mathrm{C}_{1}^{+}$ & 1 & $83.21^{\text {n.s. }}$ & $54.76^{\text {n.s. }}$ & $158.4^{\text {n.s. }}$ & $24.08^{n . s}$ \\
\hline $\mathrm{C}_{0}$ vs. $\mathrm{C}_{1}^{-}$ & 1 & $66.74^{\text {n.s. }}$ & $151.2^{\text {n.s. }}$ & $6.453^{\text {n.s. }}$ & $171.0^{\text {n.s }}$ \\
\hline $\mathrm{C}_{1}^{+}$vs. Checks & 1 & $631.7^{*}$ & $134.9^{\text {n.s. }}$ & $46.47^{\text {n.s. }}$ & $6.674^{\mathrm{n} . \mathrm{s}}$ \\
\hline $\mathrm{C}_{1}^{-}$vs. Checks & 1 & $26.69^{\text {n.s. }}$ & $426.4^{\text {n.s. }}$ & $22.88^{\text {n.s. }}$ & $46.92^{\text {n.s }}$ \\
\hline $\mathrm{C}_{1}^{+}$vs. $\mathrm{C}_{1}^{-}$ & 1 & $299.0^{\text {n.s. }}$ & $61.20^{\text {n.s. }}$ & $100.9^{\text {n.s. }}$ & $66.74^{\text {n.s }}$ \\
\hline Error & 20 & 136.1 & 183.3 & 81.73 & 95.58 \\
\hline
\end{tabular}

Mean of seed yield and realized gain from selection for high and low seed yield of barseem populations were presented in Table (5) As for khadarawi population, the first cycle of selection for high seed yield $\left(\mathrm{C}_{1}^{+}\right)$gave a significant increase in seed yield reached $483.2\left(\right.$ g. $\left.0.2 \mathrm{~m}^{-2}\right)$ over basepopulation, and $402.5\left(\mathrm{~g} .0 .2 \mathrm{~m}^{-2}\right)$ over the average of the checks. These values amount to $42.04 \%$ over the base population or $32.73 \%$ over the average of the check varieties. On the other hand, the first cycle of selection for low seed yield gave insignificant increase in seed yield reached $16.4\left(\mathrm{~g} .0 .2 \mathrm{~m}^{-2}\right)$ over the base population and $97.7\left(\mathrm{~g} .0 .2 \mathrm{~m}^{-2}\right)$ over the average of the check varieties. These increment, although, insignificant, amounted to 13.95 and $6.480 \%$ relative to the base population and the average of the checks, respectively. It was valuable to notice that, the difference between the first cycle of selection for high seed yield $\left(\mathrm{C}_{1}^{+}\right)$and the first cycle of selection for low seed yield $\left(\mathrm{C}_{1}{ }^{-}\right)$amounted to $322.8\left(\mathrm{~g} \cdot 0.2 \mathrm{~m}^{-2}\right)$, which represent superiority of the former by $24.65 \%$ over the latter.

Regarding Meskawi population, the first cycle of selection for high seed yield significantly surpassed the base population by $559.1\left(\mathrm{~g} .0 .2 \mathrm{~m}^{-2}\right)$, which amount to $57.85 \%$ of the obtained seed yield from base population $\left(\mathrm{C}_{0}\right)$. While, the superiority of the first cycle of selection for high seed yield over the average of the check varieties, although, amounted to 253.3 (g. $0.2 \mathrm{~m}^{-2}$ ) which is about $19.91 \%$, was not significant. Also, selection for low seed gave insignificant increase of $202.2\left(\mathrm{~g} .0 .2 \mathrm{~m}^{-2}\right)$ over the base population, which amount to $20.92 \%$. Meanwhile, the obtained seed yield from the first cycle of selection for low seed yield $\left(\mathrm{C}_{1}^{-}\right)$, was inferior to the average of the checks by-103.6 (g.0.2 $\left.\mathrm{m}^{-2}\right)$ which amount to $8.14 \%$. It was valuable to notice that, the difference between the cycles of bi- directional selection $\left(\mathrm{C}_{1}^{+}-\mathrm{C}_{1}^{-}\right)$ amounted to a significant value of $356.9\left(\right.$ g. $\left.0.2 \mathrm{~m}^{-2}\right)$ which reached $30.54 \%$ over selection for low seed yield.
Concerning Helaly population, the first cycle of selection for high seed yield $\left(\mathrm{C}_{1}^{+}\right)$, significantly surpassed the base population by 411.3 (g. $0.2 \mathrm{~m}^{-2}$ ) which amount to $34.6 \%$ over the base population. Also, that cycle significantly surpassed the average of check varieties by $287.9\left(\mathrm{~g} .0 .2 \mathrm{~m}^{-2}\right)$ which amount to $21.95 \%$ over the average of the checks. While, the superiority of the first cycle selection for low seed yield $\left(\mathrm{C}_{1}^{-}\right)$the base population or the average of the checks, although, reached 5.89 and $-4.07 \%$, had not reached the level of significance. Meanwhile, the difference between bi- directional cycles of selection reached $341.3\left(\mathrm{~g} .0 .2 \mathrm{~m}^{-2}\right)$, which, represent superiority of $\left(\mathrm{C}_{1}^{+}\right)$over $\left(\mathrm{C}_{1}^{-}\right)$by $27.13 \%$.

Mean of seed yield and realized gain \% from bidirectional selection of Serow population, failed to reach the level of significance. The insignificant superiority of $\left(\mathrm{C}_{1}^{+}\right)$over the base population amounted to 12.89 and $30.50 \%$ over the base population and the average of the checks, while, $\left(\mathrm{C}_{1}{ }^{-}\right)$ cycle gave insignificant reduction of $6.973 \%$ in seed yield relative to the base population. Also, the difference between $\left(\mathrm{C}_{1}^{+}\right)$and $\left(\mathrm{C}_{1}^{-}\right)$Although reached $274.1\left(\mathrm{~g} .0 .2 \mathrm{~m}^{-2}\right)$ was not significant.

The available literature that disused the response of barseem clover to selection was mainly directed for high yield expression. Bakheit (1989) applied mass and family selection for high seed yield in Fahl barseem clover Results showed a realized gains from mass selection of 6.1 and $9.5 \%$ in fresh forage yield 5.6 and $10.9 \%$ in protein yield and 13.2 and $16.2 \%$ for seed yield for the two successive cycles over the base population, respectively. The realized gain from family selection in the second cycle was $17.5 \%$ over base population in seed yield. A correlated responses in forage and protein yields and seed index reached $11.3,13.4$ and $3.2 \%$ over the base population. $\mathrm{He}$ added that week correlation was noticed between seed and forage yield. Martiniello and Lannucci (1998) applied selection among maternal half- sib. Families 
Table (5): Means of green forage yield $\left(\mathrm{g.0.2 \textrm {m } ^ { - 2 } )}\right.$ and realized gain from selection for high and low seed yield of barseem populations

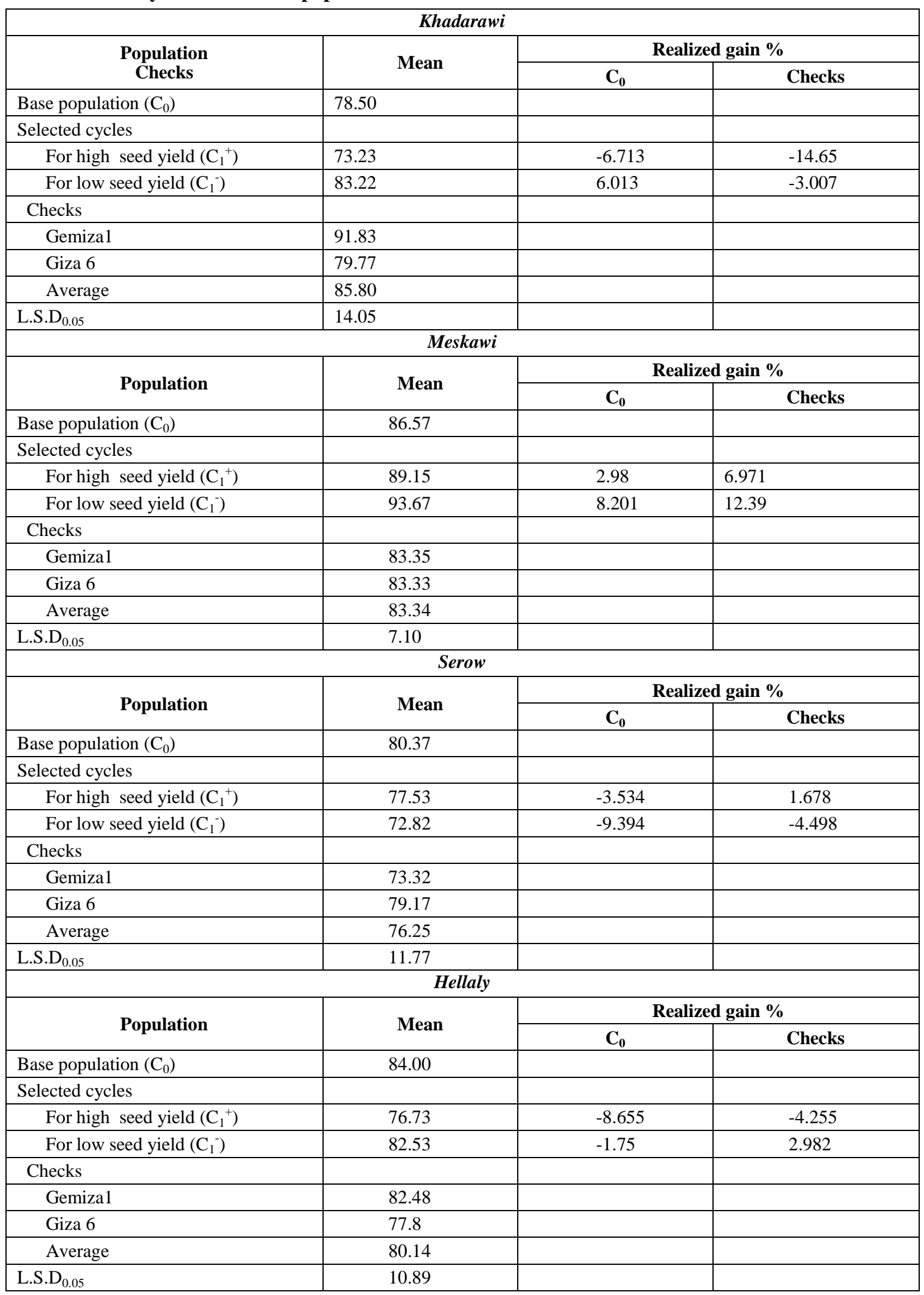


to improve seed yield of barseem clover. The results proved that selection was not effective for increasing seed yield per se. Ahmed (2000-a) made a comparison between single trait selection (total green forage yield) viacombiningability test and multiple traits (total green forage yield, dry weight of root nodules and seed yield) selection viaindependent culling levels or index selection. Selection for multiple traits was significantly much rewarding than single trait selection. A realized gains of 12.2, 17.4, 17.2, 28.5, 14.1, 17.9, and 8.0\% were scored for index selection vs.6.6, 6.0, 3.8, 10.3, 7.9, 55.1 and 4.5 for single- trait selection for total green forage, dry forage, protein and seed yields, seed index, dry weight of nodules and leaves, stem ratio, relative to base population. The realized gains from independent culling selection were significantly similar to those resulted from index selection. Ahmed (2006b) evaluated three methods of recurrent selection in improving protein yield and correlated responses in forage, seed yield and leaves/ stem ratio. $S_{1}$ and $S_{2}$ family selection gave similar increase in terms of response to selection and correlated response. Half-sib family selection gave the least improvement among the three tested methods. Depending on economic and time- value evaluation, $S_{1}$ family selection was proposed as the most efficient Radwan et.al (2007) discussed the influence of selection for high selfing rate to seed and forage yields of barseem cloverGenerations of selfing gave an increase in forage and seed yield. Bakheit et.al, (2007) practiced two cycles of modified mass and one cycle of family selection to improve seed yield of mono-cut (Fahl) barseem clover. The two successive cycles of mass selection gave an increase in seed yield of 13.6 and $8.50 \%$ over the base population. Gain from family selection in seed yield reached $18.5 \%$ over base population. Abdalla et. al, (2009) carried- out selection for self-fertility in barseem clover. Their results showed that high selffertility was correlated with an increase in number of tillers per plant to an extent reached in some cases $100 \%$. They proposed that, that vegetative improvement might improve flowering density and seed yield. Abd El- Naby et.al, (2014)proposed a successive generation of selection for self- fertility in barseem clover to improve seed setting and yield, followed by selection for forage improvement. Abdalla and Abd EL- Naby (2012) selected for seed yield depending on manual tripping or self- fertility. They reached that selection for manual tripping, improved cross pollinated seed yield. They added that selection for seed yield must be followed with cycles of selection for forage yield. Ahmed et.al, (2015), made a selection for high seed yield depending on a selection index two types of families were used (halfsib and $S_{1}$ - families). A realized gain in seed yield due to $S_{1}$ - family selection reached $29.4 \%$ relative to the base population or $38.19 \%$ relative to the average of the checks. The superiority of $S_{1}$ - family selection was basically due to an improvement in flowers density, number of inflorescences/ plant, number of seeds/ head and percent seed setting.

\section{Correlated response in forage yield Green forage yield:}

Correlated response to selection for high and low seed yield were presented in Tables 6 and 7 Mean squares of green forage yield for the four studied barseem populations, as affected by selection cycles were presented in Table 6 Meskawi population was the only significantly responded population to divergent selection. Meanwhile, the obtained differences in green forage yield among selection cycles of other populations had not reached the level of significance. Also, the difference between the obtained forage yields of the first cycle of selection and the base population, or between the green forage yield of the first cycle of selection for low seed-yield and the check varieties or between the first cycle of selection for high and the first cycle of selection for low seed- yields were significant in all studied barseem populations. Only for the difference between green forage yield of the first cycle of selection for high seed- yield and the checks in Khadarawi population, a significant $(\mathrm{p} \geq 0.05)$ difference had detected.

Table (6): Mean squares of dry forage yield as affected by selection cycles for the four studied barseem population

\begin{tabular}{|c|c|c|c|c|c|}
\hline \multirow{2}{*}{ Source of variation } & \multirow{2}{*}{ d.f. } & \multicolumn{4}{|c|}{ M.S. } \\
\hline & & Khadarawi & Meskawi & Helaly & Serow \\
\hline Replications & 5 & $4.144^{\text {n.s. }}$ & $7.038^{\text {n.s. }}$ & $20.22^{\text {n.s. }}$ & $5.904^{*}$ \\
\hline Selection cycles & 4 & $6.939^{\text {n.s. }}$ & $17.86^{\text {n.s. }}$ & $3.160^{\text {n.s. }}$ & $1.684^{\text {n.s. }}$ \\
\hline $\mathrm{C}_{0}$ vs. $\mathrm{C}_{1}^{+}$ & 1 & $3.020^{\text {n.s. }}$ & $3.136^{\text {n.s. }}$ & $4.675^{\text {n.s. }}$ & $4.072^{\text {n.s. }}$ \\
\hline $\mathrm{C}_{0}$ vs. $\mathrm{C}_{1}^{-}$ & 1 & $3.214^{\text {n.s. }}$ & $7.084^{\text {n.s. }}$ & $1.135^{\text {n.s. }}$ & $1.288^{\text {n.s. }}$ \\
\hline $\mathrm{C}_{1}^{+}$vs. Checks & 1 & $2.475^{\text {n.s. }}$ & $7.299^{\text {n.s. }}$ & $0.124^{\text {n.s. }}$ & $0.155^{\text {n.s. }}$ \\
\hline $\mathrm{C}_{1}^{-}$vs. Checks & 1 & $6.267^{\text {n.s. }}$ & $4.361^{\text {n.s. }}$ & $0.837^{\text {n.s. }}$ & $0.392^{\text {n.s. }}$ \\
\hline $\mathrm{C}_{1}^{+}$vs. $\mathrm{C}_{1}^{-}$ & 1 & $12.46^{\text {n.s. }}$ & $0.282^{\text {n.s. }}$ & $1.203^{\text {n.s. }}$ & $0.780^{\text {n.s. }}$ \\
\hline Error & 20 & 4.424 & 8.147 & 6.715 & 5.363 \\
\hline
\end{tabular}




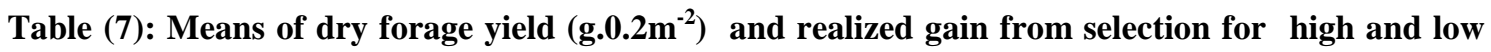
seed yield of barseem populations

\begin{tabular}{|c|c|c|c|}
\hline \multicolumn{4}{|c|}{ Khadarawi } \\
\hline \multirow{2}{*}{ Population } & \multirow{2}{*}{ Mean } & \multicolumn{2}{|c|}{ Realized gain \% } \\
\hline & & $\mathrm{C}_{0}$ & Checks \\
\hline Base population $\left(\mathrm{C}_{0}\right)$ & 14.89 & & \\
\hline \multicolumn{4}{|l|}{ Selected cycles } \\
\hline For high seed yield $\left(\mathrm{C}_{1}^{+}\right)$ & 13.89 & -6.716 & -5.446 \\
\hline For low seed yield $\left(\mathrm{C}_{1}^{-}\right)$ & 15.93 & 6.985 & 8.441 \\
\hline \multicolumn{4}{|l|}{ Checks } \\
\hline Gemiza1 & 15.79 & & \\
\hline Giza 6 & 13.58 & & \\
\hline Average & 14.69 & & \\
\hline L.S.D 0.05 & n.s. & & \\
\hline \multicolumn{4}{|c|}{ Meskawi } \\
\hline \multirow{2}{*}{ Population } & \multirow{2}{*}{ Mean } & \multicolumn{2}{|c|}{ Realized gain \% } \\
\hline & & $\mathrm{C}_{0}$ & Checks \\
\hline Base population $\left(\mathrm{C}_{0}\right)$ & 16.23 & & \\
\hline \multicolumn{4}{|l|}{ Selected cycles } \\
\hline For high seed yield $\left(\mathrm{C}_{1}^{+}\right)$ & 15.0 & -7.579 & 9.809 \\
\hline For low seed yield $\left(\mathrm{C}_{1}^{-}\right)$ & 14.70 & -9.427 & 7.613 \\
\hline \multicolumn{4}{|l|}{ Checks } \\
\hline Gemiza1 & 13.84 & & \\
\hline Giza 6 & 13.47 & & \\
\hline Average & 13.66 & & \\
\hline L.S.D ${ }_{0.05}$ & n.s. & & \\
\hline \multicolumn{4}{|c|}{ Serow } \\
\hline \multirow{2}{*}{ Population } & \multirow{2}{*}{ Mean } & \multicolumn{2}{|c|}{ Realized gain \% } \\
\hline & & $\mathbf{C}_{0}$ & Checks \\
\hline Base population $\left(\mathrm{C}_{0}\right)$ & 12.41 & & \\
\hline \multicolumn{4}{|l|}{ Selected cycles } \\
\hline For high seed yield $\left(\mathrm{C}_{1}^{+}\right)$ & 13.58 & 9.428 & 1.494 \\
\hline For low seed yield $\left(\mathrm{C}_{1}^{-}\right)$ & 13.07 & 5.318 & 2.317 \\
\hline \multicolumn{4}{|l|}{ Checks } \\
\hline Gemiza1 & 13.0 & & \\
\hline Giza 6 & 13.76 & & \\
\hline Average & 13.38 & & \\
\hline L.S.D ${ }_{0.05}$ & n.s. & & \\
\hline \multicolumn{4}{|c|}{ Hellaly } \\
\hline \multirow{2}{*}{ Population } & \multirow{2}{*}{ Mean } & \multicolumn{2}{|c|}{ Realized gain \% } \\
\hline & & $\mathbf{C}_{0}$ & Checks \\
\hline Base population $\left(\mathrm{C}_{0}\right)$ & 15.29 & & \\
\hline \multicolumn{4}{|l|}{ Selected cycles } \\
\hline For high seed yield $\left(\mathrm{C}_{1}^{+}\right)$ & 14.04 & -8.175 & -1.266 \\
\hline For low seed yield $\left(\mathrm{C}_{1}^{-}\right)$ & 14.67 & -4.055 & 3.164 \\
\hline Checks & & & \\
\hline Gemiza1 & 14.95 & & \\
\hline Giza 6 & 13.48 & & \\
\hline Average & 14.22 & & \\
\hline L.S.D 0.05 & n.s. & & \\
\hline
\end{tabular}


Means of green forage yield (g.0.2 $\mathrm{m}^{-2}$ ) and realized gain from selection for high and low seed yield of the studied barseem populations were presented in Table 7 As for Khadarawi population, selection for high seed yield resulted in a reduction of $-6.713 \%$ relative to base population. That reduction although was sound had not reached the level of significance. Meanwhile, the difference between the first cycle of selection for high seed-yield and the check varsities (Gemizal and Giza-6) showed a correlated reduction in green forage yield reached $14.65 \%$. On contrary, selection for low seed yield resulted in a correlated insignificant increase in green forage yield reached $6.013 \%$ over the base population. While, that direction of selection correlated with insignificant $3.007 \%$ reduction in green forage relative to the check varieties. Regarding Meskawi population, the only significant difference among the tested population, was that between the first cycle of selection for low seed yield and any of base population (an increase of 8.201\%) or average of the checks (an increase of $12.39 \%$ ). Selection for high seed yield, although had correlated with an increase in green forage yield reached $2.98 \%$ of the base population or $6.671 \%$ of the average of the checks had not reached the level of significance.

In both of Serow and Hellaly population, a tendency for correlated green forage yield reduction, relative to the base population were noticed, irrespective of the direction of seed yield selection (for high or low). The magnitude of reduction in green forage yield was highest with selection for low seed yield in Serow population (-9.394\% relative to base population) or with selection for high seed yield in Hellaly population $(-8.655 \%$ relative to base population).

Commonly, the correlated response in green forage yield to divergent selection for seed yield was variable among the tested base population. Khadrawi population showed a negative correlated response relative to the base population when selection was practiced for high seed yield. While, in Meskawi population, selection with low seed yield was correlated with an increase in green forage yield. On the other side, in both of Serow and Helally population, a correlated negative response in green forage yield was resulted when selection was practiced for high or low seed yield. The latter responses were not measured as significant. Bakheit (1989) applied mass and family selection for improving seed-yield of single-cut barseem clover. He reported a week correlation between seed and both of green and dry forage yields. Martiniello and Lannucci (1998) recorded that half- sib selection for seed yield was correlated with an improvement in dry matter. Ahmed(2006-a) postulated a correlated response in green, dry and leaves / stem ratio when practiced recurrent selection for protein yield. Bakheitet.al, (2007) recorded positive responses to selection in seed, fresh and dry forage yield. They added that all traits were positively correlated, except for, seed yield and forage yield. Abdalla et.al, (2009) concluded that seed yield improvement was correlated with an improvement in vegetative growth and forage yield. Abdalla and Abd EL-Naby (2012) through discussion to the relation between seedsetting potentiality and pollination pattern, they suggested the possibility of developing new improved cultivars of barseem has high seed and forage yield. Ahmed and Rady (2016) reported that green and dry forage yields in barseem clover were positively and strongly correlated.

\section{Dry forage yield:}

Mean squares of dry forage yield of barseem clover populations as affected by divergent selection for seed yield were presented in Table 8 . Non of the studied barseem populations exhibited any significant variation among the evaluated populations. Also, selection for high or low seed yields caused insignificant variations in dry forage yield. In the meantime, selected synthetic for high or low seed yield insignificantly differed from the evaluated checks in dry forage yield. Dry forage yields recorded for high seed yield selected synthetic insignificantly differed from that of synthetic selected for low seed yield.

Means of correlated response to selection for high or low seed yield as dry forage yield for each of the studied four barseem population were presented in Table 9 The insignificant correlated response to selection for high seed yield in dry forage yield of khadarawi population was a reduction of -6.716 and $-5.446 \%$ relative to base population and the average of the checks, respectively. Meanwhile, selection for low seed yield gave an increase in dry forage yield of 6.985 and $8.441 \%$ relative to base population and the average of the checks respectively. As for, Meskawi population, selection for high or low seed yield gave an insignificant negative correlated response in dry forage yield reached -7.579 and $-9.427 \%$ relative to the base population, respectively. That correlated response was insignificantly higher than the recorded dry forage yields by 9.809 and $7.613 \%$ for high seedyield and low seed-yield synthetics, respectively. Regarding Serow population, synthetics of selections for high and low seed- yields, showed insignificantly correlated higher dry forage yield of 9.428 and $5.318 \%$ relative to base populations and the average of the checks, respectively. Hellaly population, showed a correlated reduction in dry forage yield due to selection for high and low seed-yield reached 8.175 and $-4.055 \%$ relative to base population and the average of the checks respectively. 
Table (8): Simple correlation coefficients between seed yield and forage traits of barseem character for the studied population.

\begin{tabular}{|l|l|l|l|l|l|}
\hline & Khadarawi & Meskawi & Serow & Hellaly & Over all \\
\hline Green forage yield & -0.346 & +0.030 & +0.039 & -0.152 & -0.062 \\
\hline Dry forage yield & -0.062 & -0.081 & -0.045 & -0.266 & -0.188 \\
\hline
\end{tabular}

Commonly, the correlated response in dry forage yield to selection for high seed-yield, although, insignificant, was negative relative to the base population in all studied barseem populations, except, for Serow population that showed positive correlated response.

Bakheit (1989) applied mass and family selection for improving seed-yield of single-cut barseem clover. He reported a week correlation between seed and both of green and dry forage yields. Martiniello and Lannucci (1998) recorded that half- sib selection for seed yield was correlated with an improvement in dry matter. Ahmed (2006-a) postulated a correlated response in green, dry and leaves / stem ratio when practiced recurrent selection for protein yield. Bakheit et. al, (2007) recorded positive responses to selection in seed, fresh and dry forage yield. They added that all traits were positively correlated, except for, seed yield and forage yield. Abdalla et. al, (2009) concluded that seed yield improvement was correlated with an improvement in vegetative growth and forage yield. Abdalla and Abd EL-Naby (2012) through discussion to the relation between seed-setting potentiality and pollination pattern, they suggested the possibility of developing new improved cultivars of barseem has high seed and forage yield. Ahmed and Rady (2016) reported that green and dry forage yields in barseem clover were positively and strongly correlated.

\section{Correlation between seed and forage yields}

Correlation matrix that described the relation between seed yield of the evaluated populations (cycle one of selection to high seed yield, cycle one of selection to low seed yield, base population and the two check varieties and forage characters (green and dry forage yields) were presented in Table 10 Green forage yields were positively (insignificant) correlated with seed yields of Meskawi and Serow populations. While, a negative correlation was expressed in both of Khadarawi and Hellaly population. Over all the studied population, that correlation was negative $(-0.062)$. Meanwhile, dry forage yields were negatively correlated with seed yields in all studied populations. Over all populations, that correlation was found negative. These results match true with other researchers finding. Bakheit (1986) stated that plant height was positively correlated with forage (dry and fresh) yield, but, was negatively correlated with protein yield. Ahmed (2006) found that the correlation between dry forage yield and each of plant height and number of tillers were positive. The recent results might indicate that the changes in correlation pattern under selection may result from a reduction in variance within selection units (families). In unselected characters, entries might show a greater likelihood of significant correlations than do the plants overall (Collins et.al, 1998).

\section{In conclusion}

As for khadarawi population, the first cycle of selection for high seed yield $\left(\mathrm{C}_{1}{ }^{+}\right)$gave a significant increase in seed yield reached $483.2\left(\mathrm{~g} .0 .2 \mathrm{~m}^{-2}\right)$ over base- population, and $402.5\left(\right.$ g. $\left.0.2 \mathrm{~m}^{-2}\right)$ over the average of the checks. These values amount to $42.04 \%$ over the base population or $32.73 \%$ over the average of the check varieties.The first cycle of selection for low seed yield gave insignificant increase in seed yield reached $16.4\left(\mathrm{~g} .0 .2 \mathrm{~m}^{-2}\right)$ over the base population and $97.7\left(\right.$ g. $\left.0.2 \mathrm{~m}^{-2}\right)$ over the average of the check varieties. These increments, although, insignificant, amounted to 13.95 and $6.480 \%$ relative to the base population and the average of the checks, respectively. It was valuable to notice that, the difference between the first cycle of selection for high seed yield $\left(\mathrm{C}_{1}^{+}\right)$and the first cycle of selection for low seed yield $\left(\mathrm{C}_{1}^{-}\right)$amounted to $322.8\left(\right.$ g. $\left.0.2 \mathrm{~m}^{-2}\right)$, which represent superiority of the former by $24.65 \%$ over the latter.

Regarding Meskawi population, the first cycle of selection for high seed yield significantly surpassed the base population by 559.1 (g.0.2m-2), which amount to $57.85 \%$ of the obtained seed yield from base population $(\mathrm{C} 0)$. While, the superiority of the first cycle of selection for high seed yield over the average of the check varieties, although, amounted to 253.3 (g.0.2m-2) which is about $19.91 \%$, was not significant. Also, selection for low seed gave insignificant increase of $202.2\left(\mathrm{~g} .0 .2 \mathrm{~m}^{-2}\right)$ over the base population, which amount to $20.92 \%$. Meanwhile, the obtained seed yield from the first cycle of selection for low seed yield $\left(\mathrm{C}_{1}^{-}\right)$, was inferior to the average of the checks by -103.6 (g. $0.2 \mathrm{~m}^{-2}$ ) which amount to $8.14 \%$. It was valuable to notice that, the difference between the cycles of bidirectional selection $\left(\mathrm{C}_{1}{ }^{+}-\mathrm{C}_{1}{ }^{-}\right)$amounted to a significant value of 356.9 (g. $0.2 \mathrm{~m}^{-2}$ ) which reached $30.54 \%$ over selection for low seed yield. 
Concerning Helaly population, the first cycle of selection for high seed yield $(\mathrm{C} 1+)$, significantly surpassed the base population by 411.3 (g.0.2m-2) which amount to $34.6 \%$ over the base population. Also, that cycle significantly surpassed the average of check varieties by 287.9 (g.0.2m-2) which amount to $21.95 \%$ over the average of the checks. He superiority of the first cycle selection for low seed yield $\left(\mathrm{C}_{1}{ }^{-}\right)$over the base population or the average of the checks, although, reached 5.89 and - 4.07\%, had not reached the level of significance. The difference between bi- directional cycles of selection reached 341.3 (g.0.2 $\mathrm{m}^{-2}$ ), which, represent superiority of $\left(\mathrm{C}_{1}^{+}\right)$over $\left(\mathrm{C}_{1}^{-}\right)$by $27.13 \%$.

Mean of seed yield and realized gain $\%$ from bidirectional selection of Serow population, failed to reach the level of significance. The insignificant superiority of $\left(\mathrm{Cl}^{+}\right)$over the base population amounted to 12.89 and $30.50 \%$ over the base population and the average of the checks, while, $\left(\mathrm{C}^{-}\right)$cycle gave insignificant reduction of $6.973 \%$ in seed yield relative to the base population. Also, the difference between $\left(\mathrm{Cl}^{+}\right)$and $\left(\mathrm{Cl}^{-}\right)$Although reached $274.1\left(\right.$ g. $\left.0.2 \mathrm{~m}^{-2}\right)$ was not significant.

Commonly, the correlated response in green forage yield to divergent selection for seed yield was variable among the tested base population. Khadrawi population showed a negative correlated response relative to the base population when selection was practiced for high seed yield. While, in Meskawi population, selection with low seed yield was correlated with an increase in green forage yield. On the other side, in both of Serow and Helally population, a correlated negative response in green forage yield was resulted when selection was practiced for high or low seed yield. The latter responses were not measured as significant.

\section{RFERENCES}

Abballa, M.M.F and Z.M. Abd EL- Naby, (2012). Inbreeding and fertility in Egyption clover, (Trifolium alexandrinum ,L.). J. Phamacognosy phytotherpay, 4: 16-25.

Abballa, M.M.F., A. A. Moballah, M. S. Radwan, A. M. Soliman, A. R. Rammah and Z/m. Abd El- Naby, (2009). Inbreeding and fertility in Egyptian clover, (Trifolium alexandrinum ,L.). 2. Proceedings of the forage yield of high self- fertility selection $9^{\text {th }}$ international plant breeding conference, May 3- 5, 2009, Ismailia, Egypt, PP: 484-513.

Abd El-Naby, Zeinab. M, Wafaa,W. M. Shafie and M.A.El- Nahrawy, (2014). Genetic analysis and meternal effects in barseem clover. Life. Sci. J.11 (55): 407-418.
Abou El-Shawareb, O. (1971). Comparative efficiency of mass and recurrent selection breeding methods in the improvement of Egyptian "Barseem" (Trifolium alexanrinum, L.) Ph.D., Dissertation faculty of Agric, Cairo Univ., Egypt .

Ahmed, M. Abd El-Sattar, (1992). Improvement of barseem clover (Trifolium alexandrinum, L.) by different methods of selection. Ph.D. Dissertation, Faculty of Agriculture, Alexandria University, Egypt.

Ahmed, M.Abd EL-Sattar, (2000) .Comparison of single trait with multiple trait selection in Barseem clover (Trifoliumalexandrinum ,L.) .J. Agric. Sci. Mansoura Univ, 25: 46014613.

Ahmed, M. Abd El-Sattar, (2006- a). Response to three methods of recurrent selection in khadarawi barseem (Trifolium alexandrinum, L.). population Alex. J. Agric. Res. 51(3): 1322.

Ahmed, M. Abd El-Sattar, (2006- b). Variability, correlations and path-coefficient analysis in two populations of multi-cut Barseem clover. Alex. J. Agric. Res., 51 (2): 63-72.

Ahmed, M. Abd El-Sattar, M. N. Barakat, and A. M. S. Rady, (2015). Genotypic variation in Egyptian gene pool of barseem clover (Trifolium alexandrinum,L.). Egypt. J. Plant. Breed. 19(3):307-326.

Ahmed ,M. Abd EL-Sattar and Asmaa M. S. Rady, (2016). Response to one cycle of half- sib family selection for crown size in barseem clover "Trifolium alexandrinum, L". Egypt. J. Plant Breed. 20 (4):222 -236.

Ali, F.M, (1971).The effect of mass selection on forage yield and related traits in barseem clover (Trifolium alexandrinum, L.). M.Sc. Thesis, Cairo Univ., Giza, Egypt.

Badawy, A.S.M, (2013).Recurrent selection for seed yield in Helaly barseem clover. Ph.D. Dessirtation .Fac. Agric., Alex. Univ.,Egypt.

Bakheit, B. R., (1985). Effect of mass and family selection on productivity of Egyptian clover (Trifolium alexandrinum, L.). Assuit. J.Agric.Sci. 16: 35-46.

Bakheit, B. R., (1986). Genetic variability, genotypic and phenotypic correlations and path- coefficient analysis in Egyptian clover (Trifolium alexandrinum, L.). J. Agron. Crop Sci., 157: 58-66.

Bakheit, B.R., (1989). Selection for seed yield production of Egyptian clover (Trifolium alexandrinum, L.) c.v. Fahl. Plant Breed. 103: 278-285. 
Bakheit, B.R. M.A.Ali and A.M. Abo EL- Wafa, (2007).The efficiency of selection for seed yield in the fahl variety of Egyption (barseem) clover, (Trifolium alexandrinum, L.). J Agric. Sci. Mansoura Univ. 32 (1): 1-19.

Bodzon, Zbigniew, (2004). Correlation and heritability of the characters determining the seed yield of the long-raceme alfalfa (Medicago sativa, L.). Journal of applied genetic 45(1): 49-59.

Collins, R.P., M. T. Abberton, T.P.T. M: Chaelson Yates, I. Rhodes, (1997). Response to divergent selection for stolon characters in white clover (Trifoliumrepens, L). Cambridge University press 1129 (3); 279-285

(http:// doi. Org/ 10-1017/ S002 185969 7004796.

El-Nahrawy, M.A., (1980). A study of variation in productivity of farmers seed lots of Meskawi barseem (Trifolium alexandrinum, L.). M. Sc. Thesis, in Agronomy, Fac. Agric. Cairo Univ. Egypt.

Farid, N.I.; L.F. Tanash and A.M. Moustafa, (1972). Comparative study of some imported varieties of "Trifolium alexandrinum, L.", compared with the local variety Giza-1 and the effect of number of cuttings on their seed yield. Agric. Res .Rev. 50: 89-106.

Mahdy, E.E., (1988). Selection under two plant densities for forage yield of Meskawi clover (Trifolium alexandrinum,L.). Assiut. J. Agric. Sci. 19: 243-252.
Martiniello, P. and A. Lannucci, (1998). Genetic variability in herbage and seed yield in selected half-sib families of barseem clover (Trifolium alexandrinum,L.). Plant Breeding 117: 559-562.

MSTAT-C.(1996). Russel, D.Freed, MSTAT Director, Crop and soil Sciences Department, Michigan State University, U.S.A.

Radwan, M.S. and H.A. Abou-El-Fittoh, (1970). Evaluation of berseem clover varieties in field versus nursery plots. Contemporary Agriculture 6: 515-519.

Radwan, M. S. and A.A. Abou- El- Zahab, (1972). Analysis of growth of five varieties of barseem clover (Trifolium alexandrinum,L.). Z. Acker- Und- Pflanzenbau, 136: 238-244.

Radwan, M.S., A.M. Soliman, A.M.Rammah and Zeinab M Abd El-Naby,(2006). Selection for self-fertility in barseem clover (Trifolium alexandrinum,L.) Z.Acker-Und- Pflanzenbau, 136:238-244.

Rady, A.M.S., (2008). Estimation of morphological and genetic variations in barseem clover gene pool. M.Sc. Thesis in Crop Sci, Fac. Agric.Alex. Univ. Egypt.

Rajab, M.N., (2010). Studies on breeding of Egyptian clover (Trifolium alexandrinum,L.). Ph.D. Dissertation, Fac. Agric. Minia Univ., Egypt.

Steel, R.G.D. and J.H Torrie, (1980). Principles and Procedures of Statistics:A BiometricaL' Approach. McGraw-Hill Book Company, New York, 633pp. 


\section{الانتخاب ثنائي الاتجاه لمحصول البذور}

\section{"Trifolium alexandrinum" في أربع عشائر من البرسيم المصري}

\section{محمدعبد الستار أحمد وأسماء محمد سمير راضي ومحمد فخرى هيبة}

قسم المحاصيل، كلية الزراعة، جامعة الإسكندرية

البرسيم المصري محصول حولي سريع النمو يمتاز بأعلي إنتاجية بين الأعلاف المنزرعة في مصر • ويعتبر

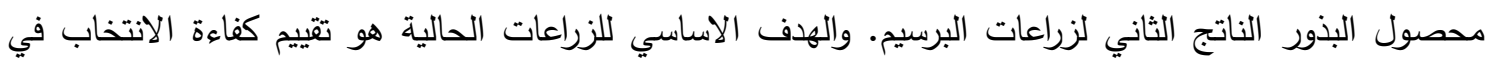

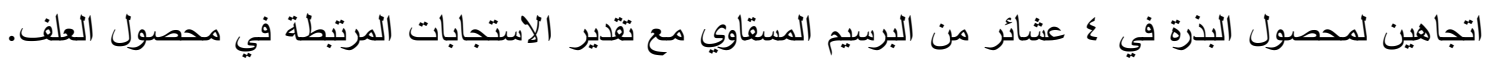

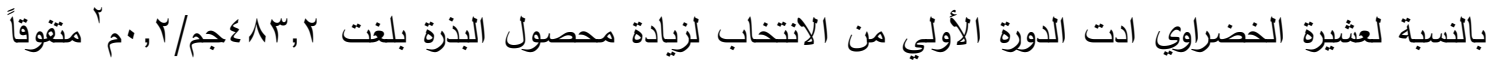

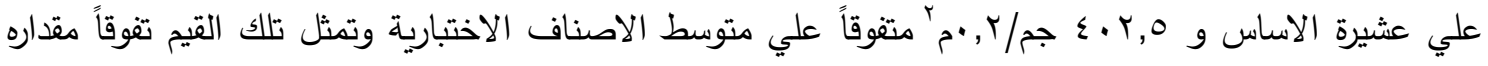

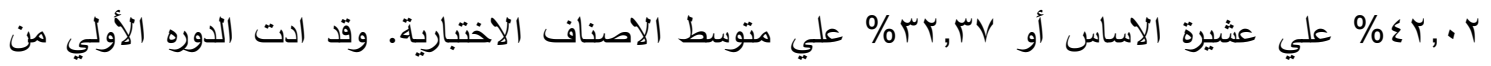

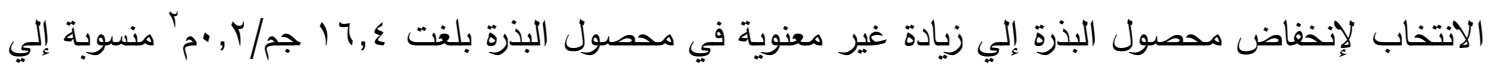

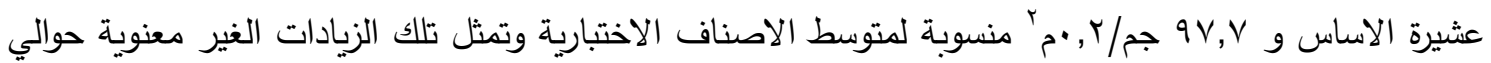

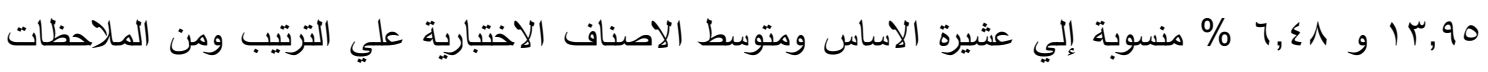

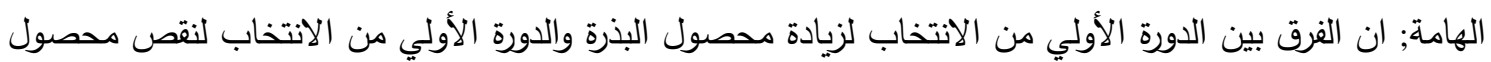

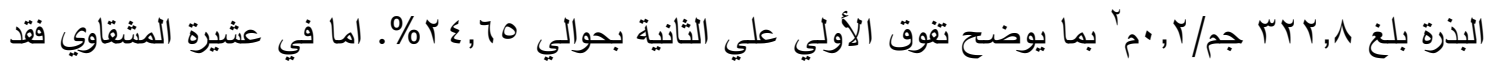

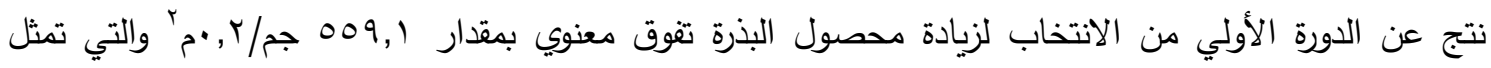

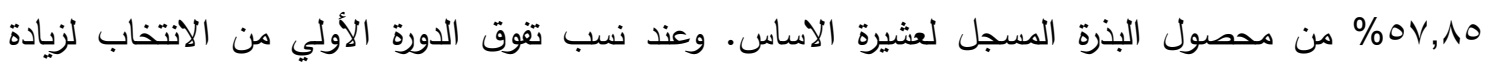

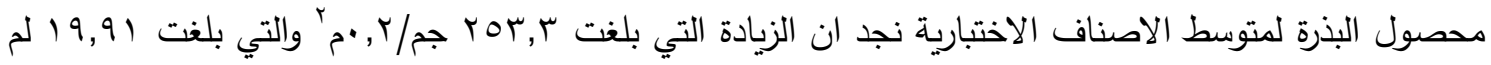

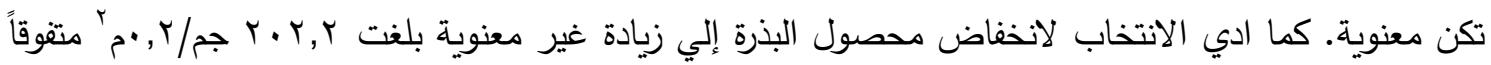

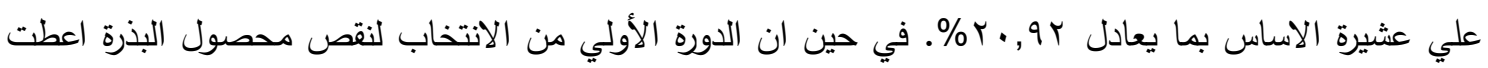

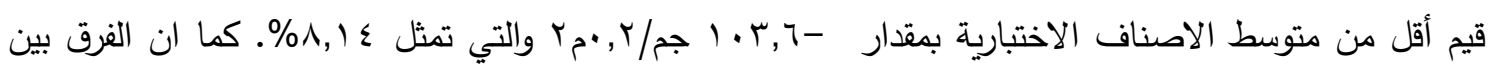

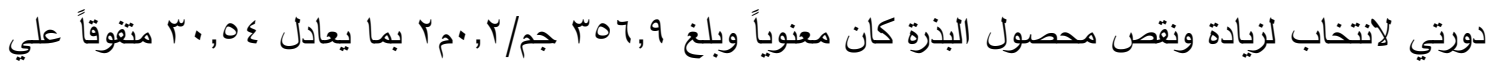

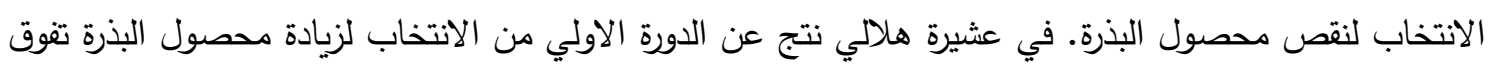

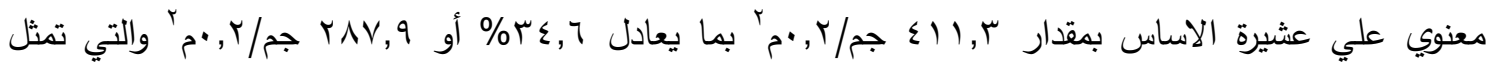

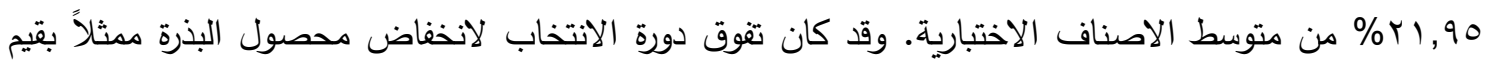

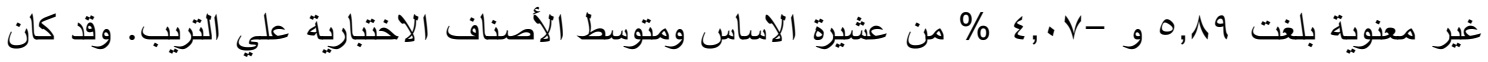

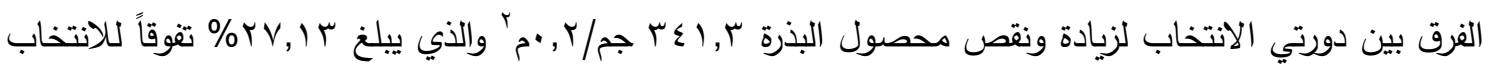

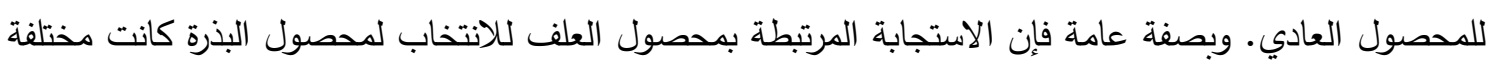

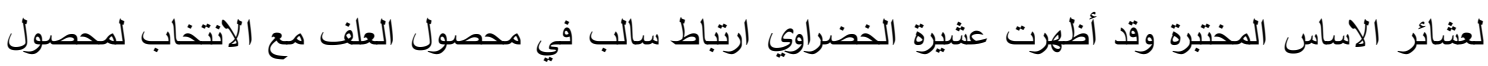

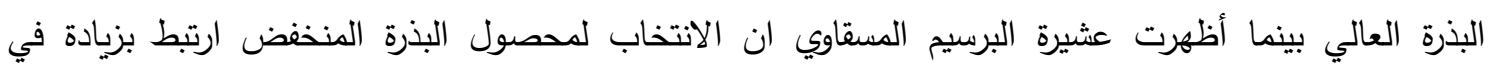

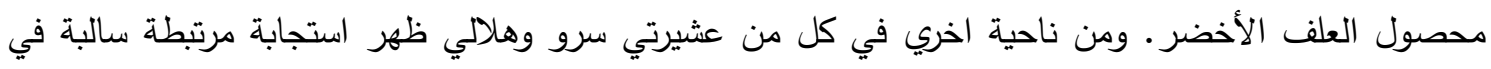

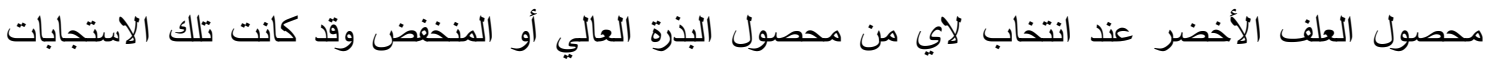

$$
\text { المرتبطة غير معنوية. }
$$


